\title{
Coastal Vegetation Database of the Southern Seas of Russia
}

\author{
Valentin Golub, Alexey Sorokin, Natalia Grechushkina, Andrej Chuvashov, Lyudmila \\ Nikolaychuk \& Viktoria Bondareva
}

\begin{abstract}
The structure and content of the Coastal Vegetation Database of the Southern Seas of Russia (GIVD ID EU-RU-005) is presented. All available phytosociological relevés from the Black Sea and Sea of Azov coasts have been collected and stored in a TURBOVEG 2.88 database. At present 2,000 of relevés are available in the database. The data are mainly used for vegetation classifications.
\end{abstract}

Keywords: Black Sea; coastal vegetation; ecoinformatics; phytosociological database; Sea of Azov.

\section{Coastal Vegetation Database of Southern Seas of Russia}

Scope: All available phytosociological relevés of different classes, from Black Sea and Sea of Azov., have been collected and stored in a TURBOVEG 2.88 database. The data are mainly used for classifications.

Status: completed and continuing

Period: 2004-2009

Database manager(s): Valentin Golub (vbgolub2000@mail.ru); Alexey Sorokin (an-sorokin@yandex.ru); Natalia Grechushkina (grenat1976@yandex.ru)

Owner: Laboratory Phytocenology, Institute of Ecology of the Volga River Basin of Russian Academy of Sciences

Web address: http://www.phytosociology.narod.ru/

Availability: according to a specific agreement

Online upload: no

Online search: no

Database format(s): TURBOVEG

Export format(s): TURBOVEG

Publication: [NA]

Plot type(s): normal plots

Plot-size range: $0.5-600 \mathrm{~m}^{2}$

Non-overlapping plots: 1,936

Total plot observations: 1,936

Estimate of existing plots: 2,000

Completeness: $97 \%$

Countries: RU: $100.0 \%$

Forest: [NA] - Non-forest: [NA]

Guilds: all vascular plants: $100 \%$; bryophytes (terricolous or aquatic): $6 \%$; lichens (terricolous or aquatic): $2 \%$; algae (terricolous or aquatic): $1 \%$

Environmental data: altitude: $18 \%$; slope aspect: $62 \%$; slope inclination: $25 \%$; microrelief: $45 \%$; surface cover other than plants (open soil, litter, bare rock etc.): $34 \%$

Performance measure(s): cover: $100 \%$

Geographic localisation: point coordinates less precise than GPS, up to $1 \mathrm{~km}: 100 \%$

Sampling periods: $2000-2009: 100.0 \%$

Information as of 2012-07-12; further details and future updates available from http://www.givd.info/ID/EU-RU-005

Valentin Golub (vbgolub2000@mail.ru), Alexey Sorokin*(an-sorokin@yandex.ru), Natalia Grechushkina (grenat1976@yandex.ru), Andrej Chuvashov (andrei.chuwashov@yandex.ru), Lyudmila Nikolaychuk (vbgolub2000@mail.ru), Viktoria Bondareva (victoria_bondareva@rambler.ru)

Laboratory of Phytosociology, Institute of Ecology of the Volga River Basin of Russian Academy of Sciences, Komzina str. 10, 445003 Togliatti, RUSSIA

*Corresponding author 